\title{
MENINGKATKAN KEMAMPUAN SISWA DALAM MENULIS PUISI MELALUI PENERAPAN METODE INQUIRY DENGAN MEDIA GAMBAR DI KELAS VI/B SDN SEMANGAT DALAM 2 KABUPATEN BARITO KUALA
}

\author{
Rahmat \\ SD Negeri Semangat Dalam 2 \\ Jl. Melati raya 1 RT 16, Komp. Griya Permata, Banjarmasin \\ email: rahmats.pd06@gmail.com
}

\begin{abstract}
ABSTRAK
Latar belakang penelitian ini yaitu rendahnya hasil belajar Pendidikan Bahasa Indonesia materi Menulis sebuah Puisi di kelas VI/B SD Negeri Semangat Dalam 2 kecamatan Alalak, selain itu motivasi dan aktivitas belajar siswa masih rendah karena guru hanya menggunakan metode ceramah dalam pembelajaran.

Penelitian ini dilaksanakan mengikuti prosedur penelitian tindakan kelas mulai tahap perencanaan, tindakan, obeservasi, dan refleksi. Subjek penelitian ini yaitu siswa kelas VI / B SD Negeri Semangat Dalam 2 Kecamatan Alalak Kabupaten Barito Kuala tahun 2014/2015 semester ganjil sejumlah 29 orang siswa. penelitian ini dalam 2 siklus, masing-masing siklus terdiri dari 2 pertemuan. Sumber data dalam penelitian ini yaitu siswa kelas VI /B, guru dan data dokumen. Data yang dihimpun merupakan data kualitatif meliputi aktivitas belajar siswa dan aktivitas aktivitas mengajar guru dan data kuantitatif mencakup hasil belajar siswa, rata-rata kelas dan ketuntasan belajar siswa, dan guru meningkat sesuai indikator keberhasilan yang ditentukan.

Hasil penelitian siklus I menunjukkan bahwa ketuntasan belajar siswa sebesar 51,72\% dengan rata-rata kelas 61,82. Sementara itu aktivitas belajar siswa dan guru memperoleh nilai $63,80 \%$ dan 74,00 (88,09\%). Dengan hasil yang diperoleh peneliti belum dapat memenuhi indicator keberhasilan, oleh Karena itu peneliti mengadakan perbaikan di siklus II supaya hasi penelitian dapat meningkat. Pada siklus II, ketuntasan belajar siswa mencapai $100 \%$ dengan rata-rata kelas 85,00 aktivitas belajar siswa meningkat menjadi 80,25, sedangkan guru meningkat menjadi 80,00 $(95,23)$.

Dengan demikian dapat disimpulkan bahwa metode inquiry dengan media gambar dapat meningkatkan hasil belajar siswa rata-rata kelas, ketuntasan belajar klasikal, dan aktivitas belajar siswa kelas VI/B SD Negeri Semangat Dalam 2 Kecamatan Alalak Kabupaten Barito Kuala

Kata kunci: aktivitas belajar, hasil belajar, metode inquiry, media gambar
\end{abstract}

\section{PENDAHULUAN}

Dalam proses belajar mengajar di sekolah siswa belajar dalam satu ruangan, waktu serta fasilitas yang sama, tetapi mempunyai perbedaan dalam hasil belajarnya, bila siswa mengikuti belajar dengan baik tanpa ada hambatan atau kesulitan dalam belajarnya, maka akan memperoleh prestasi atau hasil belajarnya dengan baik.

Awal dari sebuah proses belajar, tidak lepas dari membaca dan menulis. Pada siswa sekolah sekolah dasar (SD) membaca dan menulis merupakan hal pokok yang harus dikuasai oleh siswa, 
karena disinilah tindak lanjut proses pembelajaran. Sebagaimana yang dikemukakan oleh Tarigan (2002:30) keterampilan membaca dan menulis masih banyak menunjukkan kelemahan.

Dengan membaca diharapkan akan memperoleh pengetahuan yang bisa dikembangkan dalam bentuk tulisan seperti menulis sebuah puisi. Menulis sebuah puisi bagi siswa SD Negeri Semangat Dalam 2, masih menunjukan kelemahan, hal ini terbukti bahwa masih sedikit siswa yang menyampaikan ide atau gagasannya dalam bentuk sebuah tulisan.

Dari 29 siswa kelas VI/B SD Negeri Semangat Dalam 2, 18 orang (62\%) yang terampil dalam menulis sebuah puisi, kondisi ini sangat memprihatinkan dan menggugah untuk dilakukan suatu tindakan. Perlakuan yang perlu mendapat perbaikan diantaranya adalah model pembelajaran untuk meningkatkan keterampilan dalam menulis puisi bagi siswa SD adalah model pembelajaran dengan metode inquiry melalui media gambar baik dengan media gambar pada buku maupun media gambar pada sebuah tayangan LCD.

Dengan pendekatan ini diharapkan dapat menciptakan iklim belajar yang aktif., kreatif, efektif dan menyenangkan, sehingga pada akhirnya hasil belajar menulis sebuah puisi siswa diharapkan dapat meningkat.

\section{HASIL DAN PEMBAHASAN}

\section{Pembelajaran Bahasa Indonesia}

Pembelajaran bahasa Indonesia diarahkan untuk meningkatkan kemampuan peserta didik untuk berkomunikasi dalam bahasa Indonesia dengan baik dan benar, baik secara lisan maupun tulis, sekaligus mengembangkan kemampuan beripikir kritis dan kreatif. Peserta didik dimungkinkan untuk memperoleh kemampuan berbahasanya dari bertanya, menjawab, menyanggah, dan beradu argumen dengan orang lain.Sebagai alat ekspresi diri, bahasa Indonesia merupakan sarana untuk mengungkapkan segala sesuatu yang ada dalam diri seseorang, baik berbentuk perasaan, pikiran, gagasan, dan keinginan yang dimilikinya. Begitu juga digunakan untuk menyatakan dan memperkenalkan keberadaan diri seseorang kepada orang lain dalam berbagai tempat dan situasi. Pemahaman terhadap bahasa melalui sarana bunyi merupakan kegiatan menyimak dan pemahaman terhadap bahasa penggunaan sarana tulisan merupakan kegiatan membaca (Burhan, 2001:45)

Adapun menulis adalah keterampilan produktif dengan menggunakan tulisan. Menulis merupakan keterampilan berbahasa yang paling rumit di antara jenis-jenis keterampilan berbahasa lainnya, karena menulis bukanlah sekadar menyalin kata-kata dan kalimat-kalimat, melainkan juga mengembangkan dan menuangkan pikiran-pikiran dalam suatu struktur tulisan yang 
teratur.Kemampuan berpikir logis, kritis, kreatif, inovatif, dan bahkan inventif peserta didik perlu secara sengaja dibina dan dikembangkan. Sedangkan tujuan pembelajaran Bahasa Indonesia di SD/MI untuk aspek menulis adalah agar peserta didik memiliki kemampuan untuk melakukan berbagai jenis kegiatan menulis untuk mengungkapkan pikiran, perasaan, dan informasi dalam bentuk karangan sederhana, petunjuk, surat, pengumuman, dialog, formulir, teks pidato, laporan, ringkasan, parafrase, serta berbagai karya sastra untuk anak berbentuk cerita, puisi, dan pantun. Jadi yang sangat berhubungan dengan penelitian disini adalah tujuan pembelajaran Bahasa Indonesia aspek menulis karena siswa nantinya diharapkan terampil dalam menulis sebuah

\section{Pengertian Metode Inkuiri}

Metode inkuiri adalah suatu cara menyampaikan pelajaran dengan penelaahan sesuatu yang bersifat mencari secara kritis, analisis, dan argumentative (ilmiah) dengan menggunakan langkahlangkah tertentu menuju kesimpulan, Usman (1993:124). Metode inkuiri memberikan perhatian dalam mendorong diri siswa mengembangkan masalah. Sudyna (1986:21) mengemukakan bahwa inkuiri adalah metode mengajar yang meletakkan dan mengembangkan cara berfikir ilmiah. Metode inkuiri merupakan metode discovery artinya suatu proses mental yang lebih tingkatannya, Anita (2001:1-4). Keterlibatan aktif secara mental dalam kegiatan belajar yang sebenarnya. Inkuiri secara kooperatif memperkaya cara berpikir siswa dan mendorong mereka hakekat timbulnya pengetahuan tentative dan berusaha menghargaipenjelasan.Inkuiri atau penemuan adalah proses mental dimana siswa mengasimilasi suatu konsep atau prinsip, misalnya mengamati, menggolongkan, membuat dugaan, menjelaskan, mengukur, dan membuat kesimpulan dan sebagainya, Hamalik (2001:219). Berdasarkan beberapa definisi diatas dapat ditarik kesimpulan bahwa metode inkuiriadalah suatu cara menyampaikan pelajaran yang meletakkan dan mengembangkan cara berfikir ilmiah dimana siswa mengasimilasi suatu konsep atau prinsip, misalnya mengamati, menggolongkan, membuat dugaan, menjelaskan, mengukur, dan membuat kesimpulan dan sebagainya.

Sedangkan langkah-langkah dalam proses inkuiri (Sagala, 2003:97) adalah menyadarkan peserta didik bahwa mereka memiliki keingintahuan terhadapsesuatu, perumusan masalah yang harus dipecahkan peserta didik,. menetapkan jawaban sementara atau hipotesis, mencari informasi, data, fakta yang diperlukan untuk menjawab, permasalahan atau hipotesis, dan mengaplikasikan kesimpulan atau generalisasi dari situasi baru. Adapun keunggulan metode inquiry diantaramya menekankan kepada pengembangan aspek kognitif, afektif dan psikomotor yang seimbang, sehingga pembelajaran melalui strategi ini dianggap lebih bermakna,.memberikan kesempatan kepada siswa untuk belajar sesuai dengan gaya belajarnya., dan sesuai dengan perkembangan 
psikologi belajar modern yang menganggap belajar adalah proses perubahan tingkah laku lewat pengalaman, serta ampu melayani kebutuhansiswa yang memiliki kemampuan di atas ratarata, sehingga siswa yang memiliki kemampuan belajar bagus tidak akan terhambat oeh siswa yang lemah dalam belajar.

\section{Pengertian Media}

Ahmad Parlan Mulayono (1989:36) mengemukakan pendapatnya bahwa media adalah bahan sebagai perantara bagi seorang seniman untuk mewujudkan sebuah karya yang mempunyai bentuk dan ukuran. Oemar Hamalik (1986 : 23), bahwa media pendidikan adalah alat, metode, dan teknik yang digunakan dalam rangka lebih mengefetifkan komunikasi dan interaksi antara guru dan siswa dalam proses pendidikan dan pengajaran di sekolah. Sedangkan menurut Soeparno (1987:1) Media adalah suatu alat yang dipakai sebagai saluran (chanel) untuk menyampaikan suatu pesan (message) atau informasi dari suatu sumber (resource) kepada penerimanya (receiver). Menurut tim penyususun Kamus Besar Bahasa Indonesia (Depdikbud 2008:250) bahwa gambar adalah tiruan barang yang dibuat dengan coretan pensil dan sebagainya pada kertas dan sebagainya. Media gambar adalah salah satu dari sekian banyak media yang dapat digunakan dalam pengajaran menulis sebuah puisi. Karena media gambar merupakan tiruan yang dibuat dengan coretan alat tulis atau lukis pada kertas atau kanvas untuk membantu siswa dalam mencurahkan ide dan perasaan melalui tulisan sehingga puisi dapat ditulis dengan melihat beberapa gambar. Jadi padapenelitian tindakan kelas ini akan digunakan metode inquiry dengan media gambar

\section{Aktivitas Mengajar Guru}

Dalam pembelajaran menulis puisi melalui model inquiry ini guru dituntut memilikiketerampilanyang kompleks, seperti membuka pelajaran,bertanya memberi penguatan, mengadakan variasi, menjelaskan, membimbing diskusi kelompok kecil, mengelola kelas, mengajar perseorangan, menutup pelajaran dan juga beberapa komponen dalam menutup pelajaran yang diantaranya meninjau kembali penguasaan materi pokok dengan merangkum atau menyimpulkan hasil belajar; melakukan evaluasi antara lain dengan cara mendemonstrasikan keterampilan, mengaplikasikan ide baru pada situasi mengeksplorasi pendapat siswa sendiri, dan memberikan soal-soal tertulis. Dari penjelasan di atas dapat ditarik kesimpulan bahwa dalam pembelajaran guru perlu memiliki berbagai macam keterampilan mengajar, sedangkan aktivitas guru dalam pembelajaran menulis puisi melalui penerapan metode inquiry dengan media gambar. 


\section{Aktivitas Belajar Siswa}

Dalam proses belajar dan mengajar, guru lebih menimbulkan aktivitas siswa dalam berpikir maupun berbuat. Bila siswa menjadi partisipasi yang aktif, makai memiliki ilmu pengetahuan itu dengan baik. Akktivitas merupakan prinsif dan asas yang sangat penting di dalam interaksi belajar mengajar. Dalam kegiatan belajar, subjek siswa harus aktif berbuat dengan kata lain bahwa dalam belajar sangat diperlukannnya adanya aktivitas, tanpa aktivitas proses belajar tidak mungkin berlangsung dengan baik, Slameto (2010:36).

\section{Hasil Belajar Siswa}

Menurut Hamalik (2001:210) Evaluasi adalah suatu proses terus menerus, bukan pada akhir pengajaran, tetapi dimulai sebelum dilaksanakannya pengajaran sampai berakhirnya pengajaran. Menurut Dimyati dan Mudjiono (2016:191) mengemukakan bahwa evaluasi adalah proses pemberian atau menentukan nilai kepada objek tertentu berdasarkan kriteria tertentu. Hasil belajar merupakan hasil dari suatu interaksi tindakan mengajar. Menurut Arikunto (2008:3) evaluasi artinya menilai (tetapi dilakukan dengan menukur metode terlebih dahulu). Mengukur adalah membandingkan sesuatu dengan satu ukuran, sedangkan menilai adalah mengambil suatu keputusan terhadap sesuatu dengan ukuran baik atau buruk. Jadi, hasil belajar merupakan hasil dari suatu interaksi tindakan mengajar yang dapat diukur dan dinilai dengan eavaluasi.

\section{Kerangka Berpikir}

Agar kerangka pemikiran yang ditujukan untuk mengrahkan jalannya penelitian tindakan tidak menyimpang dari pokok permasalahan, maka kerangka pemikiran dapat digambarkan dalam sebuah skema agar peneliti mempunyai gambaran yang jelas dalam penelitian. Skema kerangka pemikiran ini dapat dilihat pada gambar berikut.

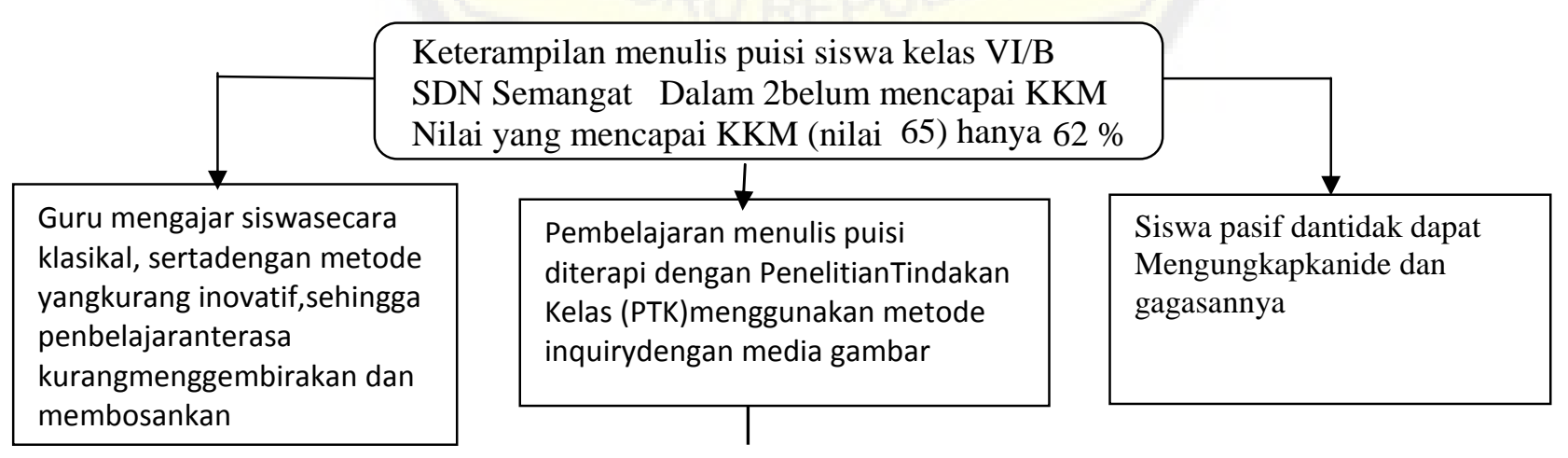


Kelebihan pembelajaran menulis puisi menggunakan metode picture and picture denganmedia gambar :

1) Materi yang diajarkan lebih terarah karena pada awal pembelajaran gurumenjelaskan kompetensi yang harus

dicapai dan materi secara singkat terlebihdahulu.

2) Siswa lebih cepat menangkap materi ajar karena guru menunjukkan gambargambarmengenai materi yangdipelajari.

3) Dapat meningkat daya nalar atau daya pikir siswa karena siswa disuruh guru untukmenganalisa gambar yang ada.

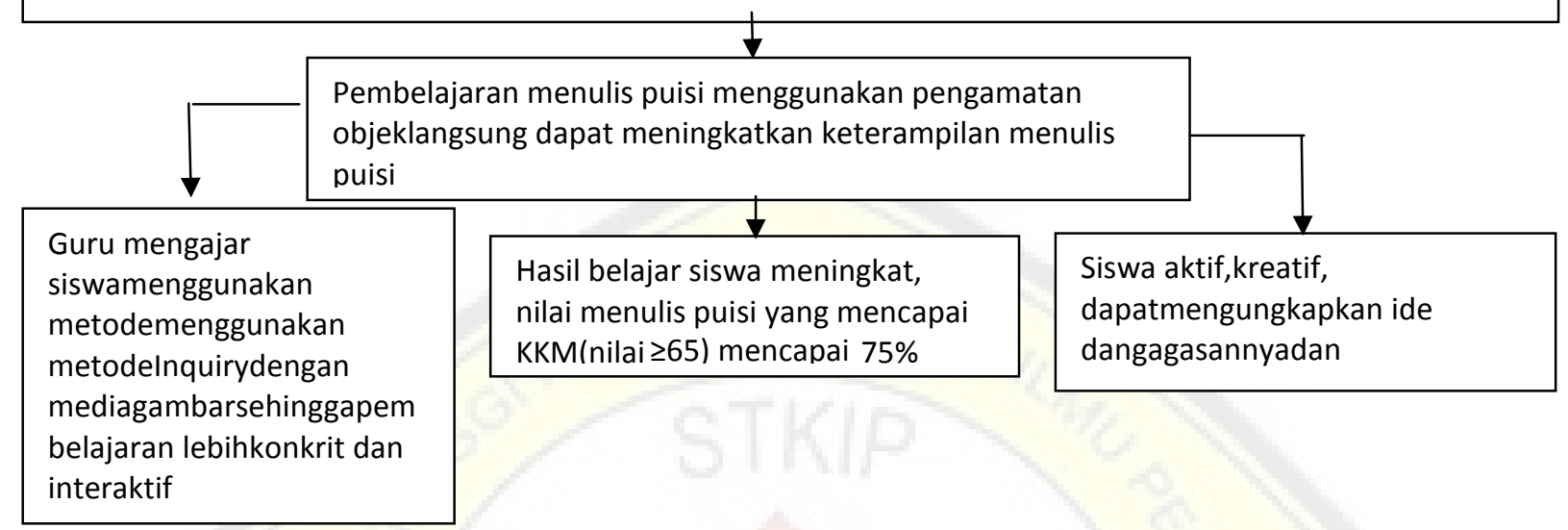

\section{Hipotesis Tindakan}

Hipotesis tindanakan dalam Penelitian Tindakan Kelas ini adalah sebagai berikut :

1. Jika melalui metode inquiry dengan media gambar aktivitas mengajar guru dalammenulis puisi bagi siswa kelas VI/B SDN Semangat Dalam2 Kecamatan Alalak Kabupaten Barito Kuala dapat ditingkatkan.

2. Jika melalui metode inquiry dengan media gambar aktivitas siswa dalam menulis puisi bagi siswa kelas VI/B SDN Semangat Dalam2 Kecamatan Alalak Kabupaten Barito Kuala dapat ditingkatkan.

3. Jika melalui metode inquirydengan media gambar hasil belajar siswa untuk menulis puisi bagi siswa kelas VI/B SDN Semangat Dalam 2 Kecamatan Alalak Kabupaten Barito Kuala dapat ditingkatkan

\section{Hasil}

Penelitian ini dilaksanakan dalam dua siklus, yaitu siklus I dan siklus II pada tanggal 04 Agustus sampai dengan 30 September 2015 di SDN Semangat Dalam 2 Kecamatan Alalak. Hasil penelitian yang telah dilakukan oleh guru pada siklus I dan siklus II di SDN Semangat Dalam 2 Kecamatan Alalak menunjukkan belum adanya peningkatan pada performasi guru. 


\section{Deskripsi Data Aktivitas Guru pada Siklus I}

Aktivitas guru yang dinilai ada siklus I yang dijadikan sebagai penilaian pendahuluan, kegiatan inti, dan kegiatan penutup. Dimana hasil aktivitas ini dapat kita lihat perolehan datanya pendahuluan berjumlah 22, kegiatan inti terdiri dari ekspolorasi, elabolarasi, dan konfimasi yang memperoleh 31, serta penutup 21 sehingga keseluruhan berjumlah 74 sehingga memperoleh ratarata sebesar 3,52 dan persentasenya adalah 88,09\%. Berdasarkan data hasil pada siklus I nilai aktivitas guru dalam kegiatan pembelajaran sudah mencapai $88,09 \%$ dan sudah mencapai indikator yang ditetapkan minimal $\geq 65 \%$.

\section{Deskripsi Data Aktivitas Belajar Siswa Siklus I}

Setiap pertemuan siswa dalam jumlah lengkap yaitu 29 orang. Aktivitas belajar siswa siklus I diselenggrakan 2 kali pertemuan yang mana pertemuan pertama dilaksanakan pada tanggal 10 Agustus 2015 dan pertemuan kedua dilaksanakan pada tanggal 19 Agustus 2015.

Tabel 1 Rekapitulasi Hasil Observasi Aktivitas Belajar Siswa Siklus I

\begin{tabular}{|c|c|c|c|c|c|c|c|}
\hline \multirow{2}{*}{ No } & \multirow{2}{*}{$\underline{\text { Aktivitas yang diamati }}$} & \multicolumn{2}{|c|}{ Per I } & \multicolumn{2}{|c|}{ Per II } & \multirow{2}{*}{$\begin{array}{l}\text { Rata-rata } \\
\text { Persentasi }\end{array}$} & \multirow[t]{2}{*}{ Kualifikasi } \\
\hline & & $\mathbf{F}$ & $\%$ & $\mathbf{F}$ & $\%$ & & \\
\hline 1. & $\underline{\text { Keantusiasan siswa mengikuti pembelajaran }}$ & 26 & 89 & 28 & 96 & $\mathbf{9 2 , 5 0}$ & Sangat Aktif \\
\hline 2. & Keaktifan siswa dalam bertanya kepada guru & 17 & 58 & 19 & 65 & $\mathbf{6 1 , 5 0}$ & Aktif \\
\hline 3. & $\begin{array}{l}\text { Keberanian siswa dalam menjawab } \\
\text { pertanyaan }\end{array}$ & 15 & 52 & 17 & 59 & $\mathbf{5 5 , 5 0}$ & $\underline{\text { Aktif }}$ \\
\hline 4. & Ketepatan siswa dalam menjawab pertanyaan & 12 & 41 & 14 & 48 & 44,50 & Kurang Aktif \\
\hline 5. & Keaktifan siswa dalam menulis sebuah puisi & 27 & 93 & 28 & 97 & 95,00 & Sangat Aktif \\
\hline 6. & $\begin{array}{l}\text { Keberanian siswa dalam mempresentasikan } \\
\text { hasil pekerjaannya }\end{array}$ & 15 & 52 & 17 & 59 & $\mathbf{5 5 , 5 0}$ & Aktif \\
\hline$\underline{7 .}$ & Menyimpulkan Materi Pelajaran & 20 & 68 & 24 & 83 & 75,00 & Sangat Aktif \\
\hline \multicolumn{6}{|c|}{ Jumlah } & 480 & \multirow[t]{2}{*}{$\underline{\text { Aktif }}$} \\
\hline \multicolumn{6}{|c|}{ Rata-Rata } & 68,58 & \\
\hline
\end{tabular}

Sedangkan untuk hasil belajar siswa pada siklus I pertemuan 1 dan pertemuan 2 bisa kita lihat pada rata-rata klasikalnya dan pencapaian ketuntasan belajar pada tabel di bawah ini :

Tabel 2 Ketuntasan Hasil Belajar Siswa pada Siklus I

\begin{tabular}{|c|c|c|c|}
\hline \multirow{2}{*}{ Hasil Belajar } & \multicolumn{2}{|c|}{ Siklus I } & \multirow{2}{*}{ Kualifikasi } \\
\cline { 2 - 3 } & Banyak Siswaz & Persentase & \\
\hline Skor $\geq 65$ & $\mathbf{1 5}$ & $\mathbf{5 1 , 7 2 \%}$ & Tunyas \\
\hline Skor $\leq 65$ & $\mathbf{1 4}$ & $\mathbf{4 8 , 2 8 \%}$ & Tidak tuntas \\
\hline Nilai Rata-rata Kelas & \multicolumn{2}{|c|}{$\mathbf{6 4 , 5 5}$} & \\
\hline
\end{tabular}


Klasikal hasil belajar sebesar 51,72\% dengan nilai rata-rata klasikal sebesar 64,55. Siswa yang mendapat nilai $\geq 65$ ada 15 dan yang mendapat nilai $\leq 65$ ada 14 siswa. Pencapaian ketuntasan belajar pada siklus I digambarkan diagram sebagai berikut :

\section{PERSENTASE KETUNTASAN HASIL BELAJAR SIKLUS I \\ - Tuntas Tidak Tunas \\ $48 \% \quad 52 \%$}

Gambar 1 Grafik Persentase Ketuntasan Hasil Belajar Klasikal Siklus I

\section{Deskripsi Data Aktivitas Guru pada Siklus II}

Aktivitas guru yang dinilai ada siklus II meliputi kemampuan guru melaksanakan pembelajaran siklus II. Komponen yang dijadikan sebagai penilaian pendahuluan, kegiatan inti, dan kegiatan penutup. hasil aktivitas ini dapat kita lihat perolehan datanya pendahuluan berjumlah 23 , kegiatan inti erdiri dari ekspolorasi, elabolarasi, dan konfimasi yang memperoleh 38, serta penutup 23 sehingga keseluruhan berjumlah 80 sehingga memperoleh rata-rata sebesar 3,81 dan persentasenya adalah $95,23 \%$.

Berdasarkan data perolehan aktivitas stklus II ternyata ada peningkatan dari pada siklus satu ini bisa kita lihat hasi pesentase siklus I sebesar 88,09\% dan siklus II sebesar 95,23\%.

\section{Deskripsi Data Aktivitas Belajar Siswa Siklus II}

Pada siklus II pertemuan ketiga dan keempat untuk pembelajaran menulis puisi menggunakan metode inquiry dengan media gambar dilakukan observasi sama dengan pertemuan kesatu dan kedua secara langsung oleh observer yaitu pada tanggal 24 Agustus 2015 pertemuan ketiga, dan pertemuan keempatnya dilaksanakan pada tanggal 01 September 2015.

Tabel 3 Rekapitulasi Hasil Observasi Aktivitas BelajarSiswa Siklus II

\begin{tabular}{|c|c|c|c|c|c|c|c|}
\hline \multirow{2}{*}{ No } & \multirow{2}{*}{ Aktivitas yang diamati } & \multicolumn{2}{|c|}{ Per I } & \multicolumn{2}{|c|}{ Per II } & \multirow{2}{*}{$\begin{array}{l}\text { Rata-rata } \\
\text { Persentasi }\end{array}$} & \multirow[t]{2}{*}{ Kualifikasi } \\
\hline & & $\mathbf{F}$ & $\%$ & $\mathbf{F}$ & $\%$ & & \\
\hline 1. & $\underline{\text { Keantusiasan siswa mengikuti pembelajaran }}$ & 29 & 100 & 29 & 100 & 100 & Sangat Aktif \\
\hline 2. & Keaktifan siswa dalam bertanya kepada guru & 24 & 82 & 25 & 86 & 84,00 & Sangat Aktif \\
\hline 3. & Keberanian siswa dalam menjawab pertanyaan & 18 & 62 & 23 & 79 & $\mathbf{7 0 , 5 0}$ & Aktif \\
\hline
\end{tabular}




\begin{tabular}{|c|l|c|c|c|c|c|c|}
\hline $\mathbf{4 .}$ & Ketepatan siswa dalam menjawab pertanyaan & $\mathbf{1 7}$ & $\mathbf{5 8}$ & $\mathbf{1 9}$ & $\mathbf{6 5}$ & $\mathbf{6 1 , 5 0}$ & Aktif \\
\hline $\mathbf{5 .}$ & Keaktifan siswa dalam menulis sebuah puisi & $\mathbf{2 8}$ & $\mathbf{8 9}$ & $\mathbf{2 9}$ & $\mathbf{1 0 0}$ & $\mathbf{9 4 , 5 0}$ & Sangat Aktif \\
\hline $\mathbf{6 .}$ & $\begin{array}{l}\text { Keberanian siswa dalam mempresentasikan } \\
\text { hasil pekerjaannya }\end{array}$ & $\mathbf{1 8}$ & $\mathbf{6 2}$ & $\mathbf{2 0}$ & $\mathbf{6 8}$ & $\mathbf{6 5 , 0 0}$ & Aktif \\
\hline 7. & Menyimpulkan Materi Pelajaran & $\mathbf{2 6}$ & $\mathbf{8 6}$ & $\mathbf{2 8}$ & $\mathbf{9 3}$ & $\mathbf{8 9 , 5 0}$ & Sangat Aktif \\
\hline \multicolumn{2}{|c|}{ Jumlah } & & $\mathbf{5 6 5}$ & \multirow{2}{*}{ Sangat Aktif } \\
\hline \multicolumn{4}{|c|}{ Rata-Rata } & $\mathbf{8 0 , 7 1}$ & \\
\hline
\end{tabular}

Untuk hasil belajar siswa pada siklus II pertemuan ketiga dan pertemuan keempat terlihat rata-rata klasikal dan pencapaian ketuntasan belajar siswa pada tabel berikut ini :

Tabel 4 Rekapitulasi Hasil Ketutasan Belajar Siklus II

\begin{tabular}{|c|c|c|c|}
\hline \multirow{2}{*}{ Hasil Belajar } & \multicolumn{2}{|c|}{ Siklus I } & \multirow{2}{*}{ Kualifikasi } \\
\cline { 2 - 3 } & Banyak Siswaz & Persentase & \\
\hline Skor $\geq 65$ & $\mathbf{2 9}$ & $\mathbf{1 0 0 \%}$ & Tuntas \\
\hline Skor $\leq 65$ & $\mathbf{0}$ & $\mathbf{0 \%}$ & Tidak tuntas \\
\hline Nilai Rata-rata Kelas & \multicolumn{2}{|c|}{$\mathbf{6 4 , 5 5}$} & \\
\hline
\end{tabular}

Ketuntasan klasikal hasil belajar sebesar $100 \%$ dengan nilai rata-rata sebesar 80,25 . Siswa yang mendapat nilai $\geq 65$ ada 29 siswa dan yang mendapat $\leq 65$ tidak ada. Pencapaian ketuntasan belajar siswa pada siklus II digambarkan pada diagram berikut :

\section{Persentase Ketuntasan Belajar Siklus II}

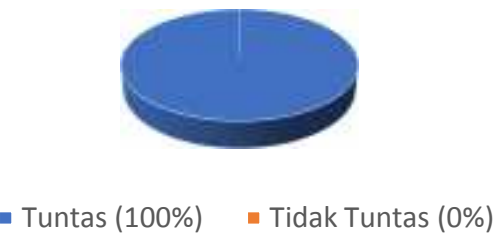

Gambar 2 Peningkatan Hasil Belajar Siswa Siklus dan Siklus II

\section{Pembahasan}

Berdasarkan penelitian yang sudah dilakukan siswa kelas VI/B SDN Semangat Dalam 2 Kecamatan Alalak Kabupaten Barito Kuala sudah merasa tidak kesulitan lagi dalam mempelajari materi menulis sebuah puisi, adanya antusiasme siswa selama pembelajaran berlangsung dan ratarata hasil belajar yang dicapai siswa setelah diterapkan pembelajaran metode inquiry dengan media gambar. Penelitian tindakan kelas ini guru berpengaruh terhadap peningkatan aktivitas dan hasil belajar siswa dalam pembelajaran dengan menggunakan metode inquiry dengan media gambar. 
Nilai aktivitas guru pada siklus I sebesar $88,09 \%$ sedangkan pada siklus II meningkat menjadi $95,23 \%$, dapat digambarkan sebagai berikut :

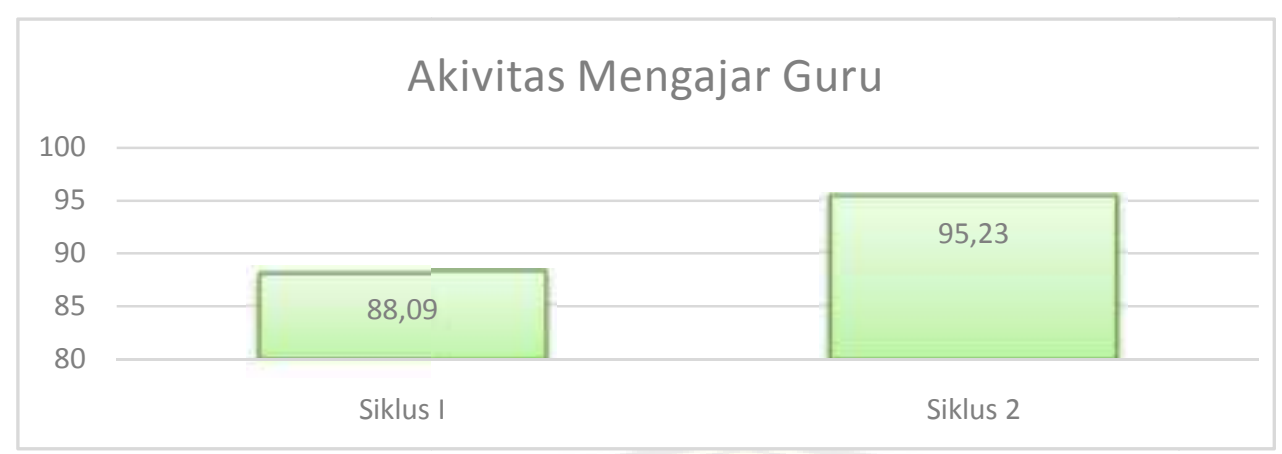

Gambar 3 Peningkatan Hasil Aktivias Mengajar Guru Siklus dan Siklus II

Hal di atas berpengaruh pada aktivitas belajar siswa dalam pelaksanaan pembelajaran dengan menerapkan metode pembelajaran inquiry dengan media gambar yang mengalami peningkatan yang lebih baik dari siklus I ke siklus II. Persentase hasil aktivitas siswa pada siklus I sebesar 68,58\% meningkat pada siklus II menjadi 80,42\%.

Tabel 5 Rekapitulasi Hasil Observasi Aktivitas Belajar Siswa Siklus I

\begin{tabular}{|c|l|c|c|}
\hline \multirow{2}{*}{ No. } & \multicolumn{1}{|c|}{ Aktivitas yang Diamati } & \multicolumn{2}{c|}{ Persentase(\%) } \\
\cline { 3 - 4 } & & $\begin{array}{c}\text { Keterangan } \\
\text { Siklus I }\end{array}$ & $\begin{array}{c}\text { Keterangan } \\
\text { Siklus I }\end{array}$ \\
\hline 1 & Keantusiasan siswa mengikuti pembelajaran & 92,50 & 100 \\
\hline 2 & Keaktifan siswa dalam bertanya kepada guru & 61,50 & 84,00 \\
\hline 3 & Keberanian siswa dalam menjawab pertanyaan & 55,50 & 70,50 \\
\hline 4 & Ketepatan siswa dalam menjawab pertanyaan & 44,50 & 61,50 \\
\hline 5 & Keaktifan siswa dalam menulis sebuah puisi & 95,00 & 92,50 \\
\hline 6 & Keberanian siswa dalam mempresentasikan hasil pekerjaannya & 55,50 & 65,00 \\
\hline 7 & Menyimpulkan Materi Pelajaran & 75,00 & 89,50 \\
\hline \multicolumn{2}{|c|}{ Rata-rata aktivitas Siswa Siklus (\%) } & 68,58 & 80,42 \\
\hline
\end{tabular}

Peningkatan aktivitas belajar siswa juga dapat dilihat pada grafik di bawah ini : Grafik Persentase Rata-rata Aktivitas Belajar Siswa pada tiap Aspek dalam 2 Siklus 


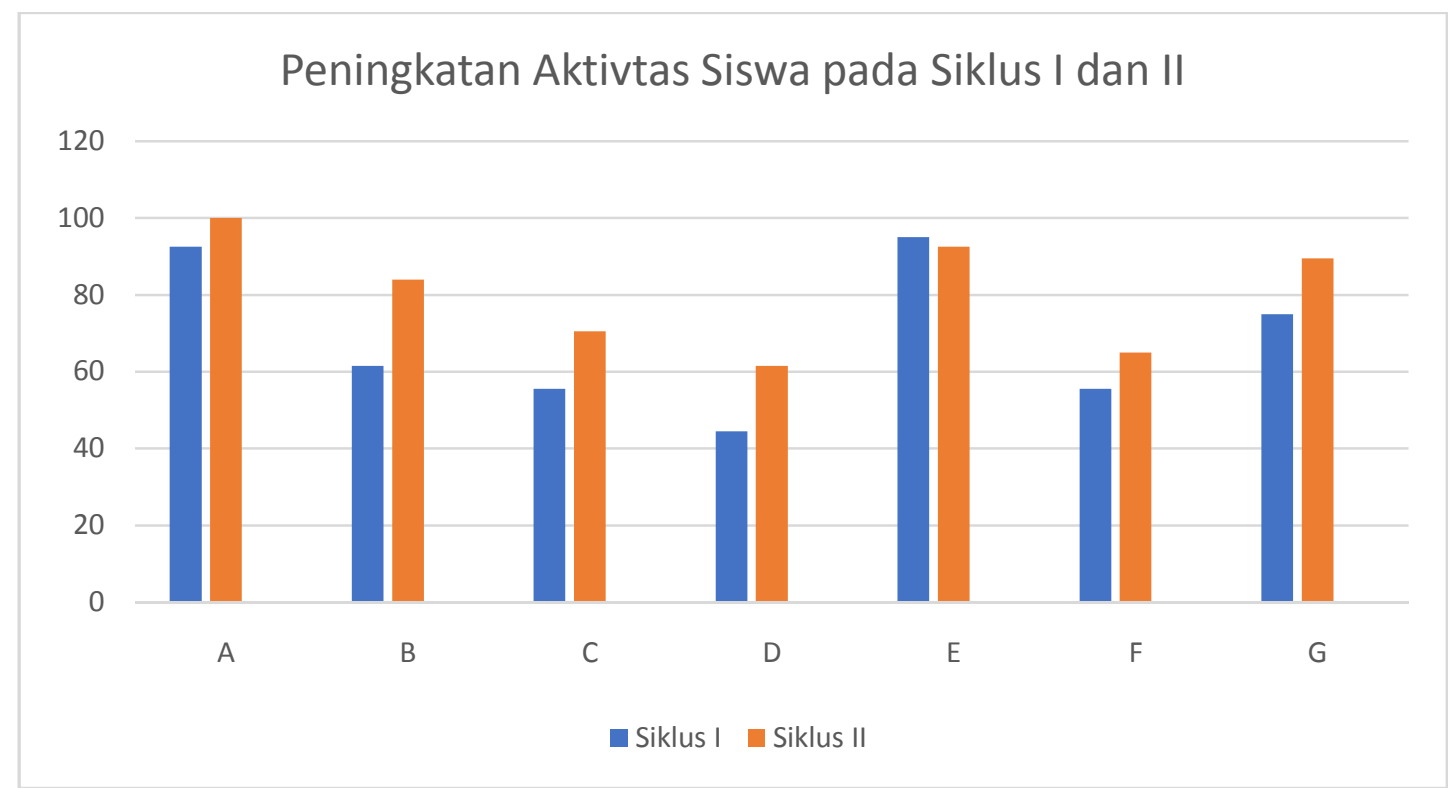

Grafik 1 Peningkatan Aktivtas Siswa pada Siklus I dan II

Pada waktu proses pembelajaran, siswa diberi kebebasan untuk berargumentasi dengan teman-temannya, selain itu siswa bertukar pikiran agar dalam penulisan sebuah puisi hasilnya bisa baik dan benar.Penerapan metode inquiry dengan media gambar ternyata juga dapat meningktakan hasil belajar siswa pada materi penulisan sebuah puisi ini terbukti adanya peningkatan pada hasil belajar siswa dari siklus I ke siklus II. Pada siklus I nilai rata-rata hasil belajar siswa sebesar 64,55\% dan ketuntasan belajar 51,72\%, sedangkan pada siklus II nilai rata-rata hasil belajar siswa meningkat menjadi 80,25 dan ketuntasan belajar siswa mencapai $100 \%$ untuk lebih jelasnya dapat kita lihat pada tabel dan grafik di bawah ini :

Tabel 6 Rekapitulasi Hasil Belajar Siswa pada Siklus I dan II

\begin{tabular}{|c|c|c|c|c|c|}
\hline \multirow[b]{2}{*}{ Hasil Belajar } & \multicolumn{2}{|c|}{ Siklus I } & \multicolumn{2}{|c|}{ Siklus II } & \multirow{2}{*}{ Keterangan } \\
\hline & $\begin{array}{l}\text { Banyak } \\
\text { Siswa }\end{array}$ & Persentasi & $\begin{array}{l}\text { Banyak } \\
\text { Siswa }\end{array}$ & Persentasi & \\
\hline Skor $\geq 65$ & 15 & $51,72 \%$ & 29 & $100 \%$ & Tuntas \\
\hline Skor $\leq 65$ & 14 & $48,28 \%$ & 0 & $0 \%$ & Tidak Tuntas \\
\hline $\begin{array}{l}\text { Nilai Rata-rata } \\
\text { Kelas }\end{array}$ & \multicolumn{2}{|c|}{64,55} & \multicolumn{2}{|c|}{80,25} & \\
\hline
\end{tabular}


Peningkatan hasil belajar siswa juga dapat dilihat pada grafik di bawah ini :

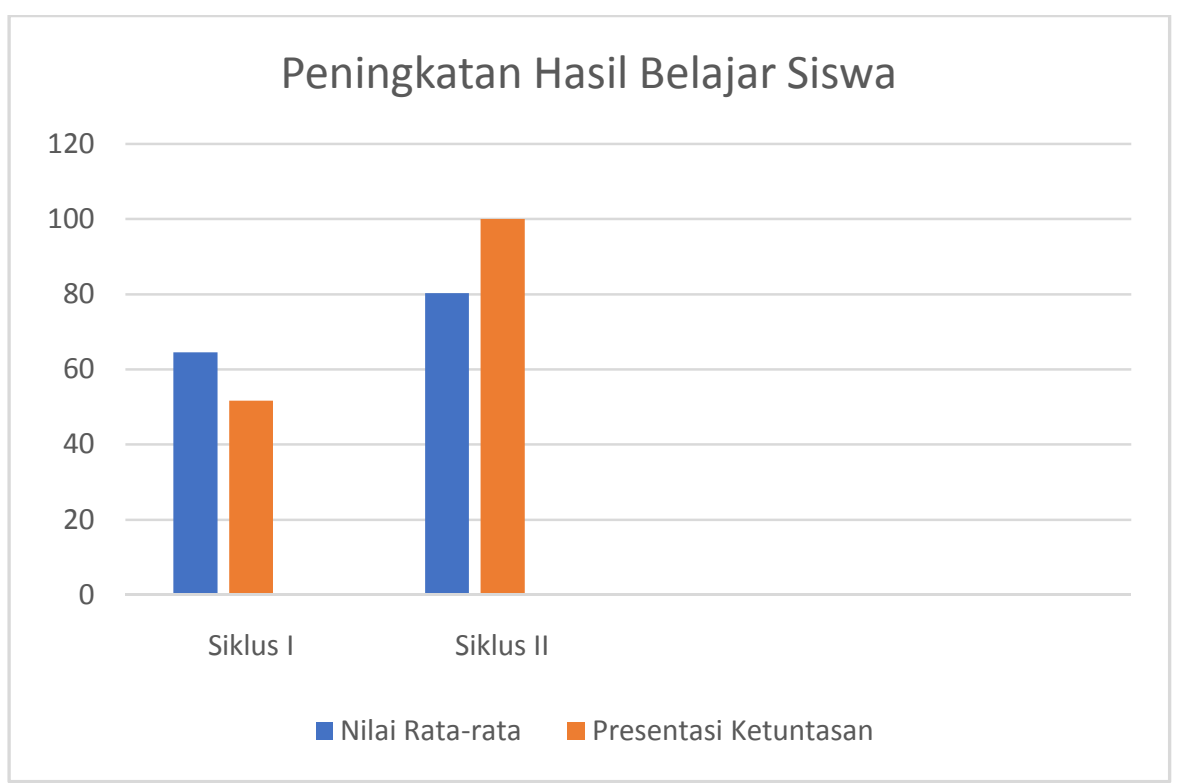

Grafik 2 Peningkatan Hasil Belajar Siswa pada Siklus I dan II

Peningkatan hasil belajar tersebut memiliki makna bahwa metode pembelajaran inquiry dengan media gambar efektif untuk pembelajaran Bahasa Indonesia pada materi menulis sebuah puisi pada tipe ini guru memberikan lesempatan kepada siswa untuk berpikir dan berimajinasi dan juga bisa bertukar pikiran dengan teman.

Proses belajar yang dilakukan siswa mengakibatkan adanya perubahan perilaku, perubahan perilaku yang dialami siswa sebagai hasil belajar ditandai dengan pemahaman siswa terhadap materi dalam menulis sebuah puisi.

Perubahan perilaku yangdiperoleh siswa sebagai hasil belajar sesuai dengan pendapat Hamali (2006:30) bahwa hasil belajar adalah terjadinya perunahan tingkah laku ketika seseorang telah belajar misalnya dari tidak tahu menjadi tahu dan dari tidak mengerti menjadi mengerti.

\section{SIMPULAN}

Berdasarkan tujuan utama penelitian yaitu untuk memecahkan permasalahan yang nyata terjaadi di dalam kelas sehingga dapat mempengaruhi dan meningkatkan kualitas pembelajaran. Tujuan penelitian ini meliputi tujuan umum dan tujuan khusus. Tujuan umum dilakukan untuk meningkatkan kualitas proses dan hasil pembelajaran bahasa Indonesia di kelas VI/B SD Negeri Semangat Dalam 2 Kecamatan Alalak Kabupaten Barito Kuala. Sedangkan tujuan khusus untuk meningkatkan aktivitas mengajar guru, aktivitas belajar siswa,hasil belajar siswa melalui metode 
inquiry dengan media gambar pada pembelajaran Bahasa Indonesia siswa kelas VI B materi menulis sebuah puisi.

Dari hasil analisis data dan pembahasan yang telah dipaparkan pada bab sebelumnya, peneliti dapat menyimpulkan bahwa penerapan metode inquiry dengan media gambar dapat meningkatkan hasil belajar siswa kelas VI B SD Negeri Semangat Dalam 2 Kecamtan Alalak Kabupaten Barito Kuala pada mata pelajaran Bahasa Indonesia yang mendukung pernyataan ini yaitu :

1. Aktivitas Mengajar Guru

Pada aktivitas guru jelas sekali terjadi peningkatan pada siklus I ke siklus II seperti yang kita ketahui pada siklus I persentasinya sebesar 88,09\% dan sedangkan pada siklus II sebesar 95,23\%, maka dari itu metode inquiry dengan media gambar ternyata dapat meningkat aktivitas mengajar guru.

\section{Aktivitas Belajar Siswa}

Dari hasil observasi terhadap aktivitas siswa selama pembelajaran dapat diketahui bahwa aktivitas siswa mengalami peningkatan di setiap siklus. Aktivitas belajar siswa di siklus I diperoleh dengan ketuntasan belajar 68,58\% dan pada siklus II diperoleh dengan ketuntasan belajar 80,42\%. Hal ini menunjukkan bahwa metode inquiry dengan media gambar dapat meningkatkan aktivitas siswa dalam pembelajaran.

3. Hasil belajar siswa

Setelah peneliti menerapkan metode inquiry dengan media gambar hasil belajar siswa yang terdiri dari ketuntasan belajar klasikal dan rata-raa nilai dapat meningkat di setiap siklus. Pada siklus I persentase ketuntasan belajar klasikal 51,72\% dengan rata-rata 64,55 sementara itu pada siklus II persentase ketuntasan belajar klasikal mencapai 100\% dengan rata-rata nilai 80,26.

\section{SARAN}

1. Hasil penelitian ini dapat memberikan masukan yang berarti bagi peningkatan mata pelajaran di kelas, oleh sebab itu bagi guru-guru lain untuk melakukan penelitian sejenis dengan pembelajaran yang lain.

2. Sebagai implekasi dari hasil ini dapat dijadikan sebagai salah satu alternatif untuk meningkatkan kualitas pemeblajaran dan hasil belajar. Oleh Karena itu kepada guru-guru khususnya guru SD disarankan dapat melakukan inovasi pembelajaran, salah satu alternatifnya adalah menggunakan metode inquiry dengan media gambar 


\section{DAFTAR RUJUKAN}

Anita, S. W. 2001. Metode Belajar Mengajar. Bandung: Alfabeta.

Arikunto, S. 2008. Prosedur Penelitian Suatu Pendekatan Praktik. Jakarta: Rineka Karya.

Depdikbud. 2008. Model-model pembelajaran yang Efektif. Semarang: Depdikbud.

Dimyati dan Mudjiono. 2016. Belajar dan Pembelajaran. Jakarta: Rineke Cipta.

Hamalik, O. 2001. Belajar Mengajar. Jakarta: Bumi Aksara.

Sagala, S. 2003. Metode Belajar Mengajar. Bandung: Alfabeta.

Usman, M.U. 1993. Belajar Mengajar. Bandung: Remaja Rosdakarya. 